\title{
THE LAW OF THE NATIONAL WAR LABOR BOARD
}

\author{
WiLliam Gorham Rice, Jr.*
}

\section{Historical Setting}

Governmental control of labor relations, so far as it existed, was, till recently, the affair of the states, rather than of the United States. In the last century, labor cases often came before the United States courts, but the legislative and executive arms of the United States did not often embrace such problems. When a major strike involved violence, the executive occasionally sent in the army or went to the courts. ${ }^{1}$ More often the President intervened as a supermediator and spokesman of public opinion. ${ }^{2}$ And it was in this capacity that the National Government first entered the field in more than a sporadic manner-through the agency of the Conciliation Service of the Department of Labor. ${ }^{3}$

Periods of severe international war demand greater activity in labor disputes by the national authority. In the first place, in wartime a larger proportion of production is for the Government and closely related to what is for the moment the chief concern of the nation-the winning of military dominance. In the second place, idleness of workers which normally is a luxury, expensive to them and to their employer, but unless accompanied by violence, no more disastrous to the public generally than are smokeless chimneys due to other causes, becomes calamitous when the smokelessness of any chimney is a calamity. Both as the purchaser of supplies for the war machine and its mass of employees and also as protector of the economic life and consumption needs of the whole population, the National Government must in wartime take an active role in curing labor disputes. And so it has in both of the World Wars.

* A.B., I914, A.M., 1915, LL.B., 1920, S.J.D., I921, Harvard University. Professor of Law, University of Wisconsin Law School. Assistant General Counsel, National Labor Board, r934; General Counsel, National Labor Relations Board, 1934; United States Labor Commissioner and member of Governing Body; International Labor Organization, 1935-1936; special legal consultant, Wage and Hour Administration, 1939-1940, 1941-1942; mediator, National War Labor Board, 1942. Contributor to legal periodicals on constitutional, international, and labor law.

${ }^{I}$ As in the notorious Pullman strike of I894. See WrTte, The Government in Lamox Disputes (1932) 63 .

"The President of the U. S. has taken a hand in some 30 great strikes since the turn of the century, sometimes only to send federal troops, but usually to endeavor to prevent or settle the dipute." Id. at 237.

' The Secretary of Labor was authorized to mediate in labor disputes when the Department was created in 1913. 37 SтAт. 738, 29 U. S. C. $\$ 5 x$. (In the same year the Newlands Act set up, for the railroad field, the Board of Mediation and Conciliation, 38 STAT. 103, but the first railroad labor legislation had been in $\mathrm{r} 888,25$ STAT. 50r.) Commissioners of conciliation soon were employed and the service has steadily expanded. 
The National War Labor Board of rgr8-Ig worked from a set of principles propounded by the War Labor Conference Board, ${ }^{4}$ composed of an equal number of representative employers and representative employees. This bipartite agency, under the double chairmanship of William Howard Taft and Frank P. Walsh, in a sense negotiated within itself a nation-wide collective bargain on certain issues; and the War Labor Board, its alter ego of identical membership, built this bargain into every collective contract or labor situation within its reach. The War Labor Board thus carried into operation through its decisions, beginning in June, rgr8, and continuing for a year, the employment code that the War Labor Conference Board had created.

Much of what was then only principles of a board, made potent by Presidential proclamation, has in 25 years become statute law:

(I) The employer's obligation to bargain collectively and not to discriminate on account of union membership; for railroads, through the Railway Labor Acts of 1926 and 1934; and, in the wide field of interstate commerce, first temporarily through Section 7 (a) of the National Industrial Recovery Act, as embodied in 1933-35 in the President's Reemployment Agreement and the NRA codes of fair competition, and then permanently through the well-matured National Labor Relations Act of 1935 .

(2) Minimum wage rates: for work done under government contracts, through the Walsh-Healy and Davis-Bacon Acts; and, in the wide field of interstate commerce, first temporarily through the NIRA and then permanently through the Fair Labor Standards Act.

Other of the principles of $19 \mathrm{r} 8$ were by their nature unsuitable except as temporary provisions, particularly that which "froze" the degree of unionization of

'The Secretary of Labor, William B. Wilson, appointed the Board on Jan. 28, 1918. Two months later it reported a plan for a War Labor Board. On April 8, x9r8, a year after the United States had gone to war, President Wilson, after reciting and approving the appointment of the War Labor Board by Secretary Wilson, proclaimed "for the information and guidance of all concerned":

"The powers, functions, and duties of the ... Board shall be: To settle by mediation and conciliation controversies arising between employers and workers in fields of production necessary for the effective conduct of the war, or in other fields of national activity, delays and obstructions in which might, in the opinion of the national board, affect detrimentally such production; to provide, by direct appointment or otherwise, for committees or boards to sit in various parts of the country where controversies arise and sccure settlement by local mediation and conciliation; and to summon the parties to controversies for hearing and action by the national board in event of failure to secure settlement by mediation and conciliation.

"The principles to be observed and the methods to be followed by the national board in exercising such powers and functions and performing such duties shall be those specified in the said report of the War Labor Conference Board dated March 29, x918, a complete copy of which is hereunto appended.

"The national board shall refuse to take cognizance of a controversy between employer and workers in any field of industrial or other activity where there is by agreement or Federal law a means of settlement which has not been invoked.

"And I do hercby urge upon all employers and employees within the United States the necessity of utilizing the means and methods thus provided for the adjustment of all industrial disputes, and request that during the pendency of mediation or arbitration through the said means and methods there shall be no discontinuance of industrial operations which would result in curtailment of the production of war necessities." 
shops. ${ }^{5}$ Even those principles that might have been permanent were abandoned as a part of government policy and public law, during the period of "return to normalcy," till the onset of economic depression brought a renewal of national support of labor standards-the Norris-LaGuardia Act of 1932, the Railway Labor Act of 1934, the National Labor Relations Act, the Social Security Act, and the Fair Labor Standards Act-all lasting products of a new economic emergency, different from, but as fateful as, that created by war. Thus nearly all of the 1918 principles that could be made permanent were already statute law in $194 \mathrm{r}$.

The first principle of 1918 , "There should be no strikes or lockouts during the war," however, was not law in I941. It had been a rule in the hour of crisis, and it was one which, as soon as the new hour of crisis struck, was immediately announced by spokesmen of all groups at the President's conference of management and labor that convened December 17, 1941, only a week after the outbreak of war. ${ }^{7}$ The other crisis provision of IgI8, the freezing of shop unionization, was urged by

\footnotetext{
" "In establishments where the union shop exists the same shall continue. . . . In establishments where union and non-union men and women now work together and the employer meets only with employees or representatives engaged in said establishments, the continuance of such conditions shall not be deemed a grievance. This declaration, however, is not intended in any manner to deny the right or discourage the practice of the formation of labor unions or the joining of the same by the workers in said establishments. ..."

Note that shop arrangements were frozen but membership in unions was left liquid. The 1942 issue of maintenance of membership apparently was never raised.

- Except perhaps for railroad labor statutes: the Transportation Act of 1920, Title III of which set up the Railroad Labor Board, and the Railway Labor Act of 1926, which abolished the Railroad Labor Board and set up the Board of Mediation, superseded in 1934 by the National Mediation Board. The last-named board must not be confused with the National Defense Mediation Board of 1941-42, of which the National War Labor Board is the successor. In this article "Mediation Board" means the board that operated from March 19, 194I, to January 12, 1942.

${ }^{7}$ This committee was similar in composition to the War Labor Conference Board of 1918 . It consisted of twelve representative industrialists, twelve labor leaders (six AFL and six CIO), a moderator (William H. Davis, now chairman of the National War Labor Board), and an associate moderator (Elbert D. Thomas, chairman of the Senate Committee on Labor and Education). Not having achieved agreement, the conference reported to the President and received in reply the following letter of appreciation and farewell.
}

Gentlemen of the Conference:

The White House, Washington, December 23, 1941.

Moderator Davis and Senator Thomas have reported to me the results of your deliberations. They have given me each proposition which you have discussed. I am happy to accept your general points of agreement as follows:

x. There shall be no strikes or lock-outs.

2. All disputes shall be settled by peaceful means.

3. The President shall set up a proper War Labor Board to handle these disputes.

I accept without reservation your covenants that there shall be no strikes or lock-outs and all disputcs shall be settled by peaceful means. I shall proceed at once to act on your third point.

Government must act in general. The three points agreed upon cover of necessity all disputes that may arisc between labor and management.

The particular disputes must be left to the consideration of those who can study the particular differences and who are thereby prepared by knowledge to pass judgment in the particular casc. I have full faith that no group in our national life will take undue advantage while we are faced by common enemies.

I congratulate you-I thank you, and our people will join me in appreciation of your great contribution.

Your achievement is a response to common desire of all men of good will that strikes and lock-outs cease and that disputes be settled by peaceful means.

May I now wish you all a Merry Christmas.

Very sincerely yours,

FrANkLin D. Roosevelt. 
management for adoption in r94I also; but labor would not agree. ${ }^{8}$ This was not surprising for, though neither the no-stoppage stipulation, which was agreed to, nor the freezing of shop unionization, which labor rejected, was wholly one-sided, it is obvious that each meant a far greater curtailment of labor's freedom than of management's. The bargain of r9I8 was fair because in exchange for these renunciations labor obtained for the war period management's undertaking (I) to bargain collectively, (2) not to discriminate against unionists, (3) to pay a decent minimum wage, etc. But since all these were required by statute in I94I, management now had nothing to offer in exchange for the freezing of shop unionization or at least did not offer anything. While labor readily recognized-to some extent even before the outbreak of war-that striking must be ruled out because of the superlative national need of production, and while this sacrifice of a group interest for the national good strengthened in the long run the position of organized labor in the councils of the nation, there was no denying that in any individual controversy labor's position was weakened so far as it had shelved the threat of collective refusal to work on the terms offered by the employer. Thus labor could properly urge in support of its plea for "union security" that this weakening of the union should be somehow balanced by action of the Government in its role of final determiner of individual controversies, when the present National War Labor Board-tripartite instead of bipartite-took up the task of serving as a substitute for strikes and lockouts in the settlement of labor disputes.

The present Board began its work on January I2th of this year ${ }^{9}$ without the

To the three principles acknowledged by both groups the employers wished to add:

"4. The Board shall be governed by the following basic policy:

"Since the right to work should not be infringed by Government order through requirement of membership in any organization, whether union or otherwise, the issue of the closed shop is not a proper subject for consideration or arbitration by the Board, and shall not be included as an issue in any dispute certified to it. The term 'closed shop' includes any provision which requires a person to become or remain a member of a labor organization in order to get or hold a job, or have preference in respect to employment.

"For the duration of the war employers shall not attempt to change the terms, in present contracts, which provide for the closed shop or any of its modifications, except where such change is necessary to conform to the law. Where a closed shop contract does not now exist it may be arrived at by voluntary negotiations between the employer and the labor organization concerned."

'Executive Order No. 9017, Jan. 12, 1942, 7 FED. REg. 237, provides:

" $I$. There is hereby created in the Office of Emergency Management a National War Labor Board, hercinafter referred to as the Board. The Board shall be composed of twelve special commissioners to be appointed by the President. Four of the members shall be representative of the public; four shall be representative of employees; and four shall be representative of employers. The President shall designate the Chairman and Vice-Chairman of the Board from the members representing the public. The President shall appoint four alternate members representative of employees and four representative of employers, to serve as Board members in the absence of regular members representative of their respective groups. Six members or alternate members of the Board, including not less than two members from each of the groups represented on the Board, shall constiute a quorum. A vacancy in the Board shall not impair the right of the remaining members to exercise all the powers of the Board.

"2. This order does not apply to labor disputes for which procedures for adjustment or settlement are atherwise provided until those procedures have been exhausted.

"3. The procedures for adjusting and settling labor disputes which might internupt work which contributes to the effective prosecution of the war shall be as follows: (a) The parties shall first resort to. direct negotiations or to the procedures provided in a collective bargaining agreement. (b) If not settled 
advantage or disadvantage of a special war labor code, such as the War Labor Conference Board had adopted to supplement existing statutory law in $19 \mathrm{r} 8$. The very national legislation which largely supplied this lack also gave the Board certain problems that did not confront the Board of Igr8-for instance the settlement of a boundary of authority with the National Labor Relations Board. It may therefore be doubted whether the Board was really any more "at large" than was the rgr8 board. Both in fact had about the same sort of freedom as a daring young man on a flying trapeze.

\section{The National Defense Mediation Board}

The fact that the Board had had a predecessor (also tripartite and of similar composition), the National Defense Mediation Board, for the preceding 8 months, was a doubtful asset, for the NDMB, after a most successful beginning, had lost luster by the withdrawal of the CIO members in protest against its refusal to recommend a union shop in certain coal mines operated by steel and chemical companies-the so-called Captive Mines case.

On the other hand, the score of cases in which that board had made formal recommendations which the parties had accepted and the two or three score more in which by mediation it had led the parties to agree, had blazed a path for the new board through some of the besetting problems of procedure and substance. ${ }^{10}$ The National War Labor Board received a further legacy from the National Defense Mediation Board-some 30 unfinished cases, most of them ClO cases that had been shelved since the Captive Mines episode in November.

Before the outbreak of war, neither the law nor (at least in many cases) any pledge restrained unions from striking; recourse to the Defense Mediation Board was therefore a mere voluntary alternative to economic battle, an alternative that would little appeal to the economically stronger party unless it would yield results substantially as favorable. One important factor that the Defense Mediation Board therefore had to consider in making decisions was the parties' economic strength in each particular controversy. Such a factor twisted the growth of a consistent law of settlement for labor disputes.

The War Labor Board was less harried by such considerations. It could deal with labor controversy in a larger way; it did not have to weigh so heavily the relative economic position of the parties before it in each particular case. All having

in this manner, the Commissioners of Conciliation of the Department of Labor shall be notified if they have not already intervened in the dispute. (c) If not promptly settled by conciliation, the Scerctary of Labor shall cercify the dispute to the Board, provided, however, that the Board in its discretion after consultation with the Secretary may take jurisdiction of the dispute on its own motion. After it takes jurisdicion, the Board shall finally determine the dispute, and for this purpose may use mediation, voluntary arbitration, or arbitration under rules established by the Board."

As another article in this issue covers the jurisdiction and procedure of the Board, this article is devoted to the substance of Board decisions.

${ }^{10}$ The Bureau of Labor Statistics will shortly publish a study of the work of the National Defense Mediation Board prepared by Louis L. Jaffe and William G. Rice, Jr., as BLS BuLLetiN No. 714. 
undertaken, by pledge of their spokesmen in the conference of December, I94I, repeated on many public occasions, not to stop production, the Board did not have to ask first of all, What will these parties accept in place of a bout of picket and boycott? but rather with a long look ahead, What is the best settlement in the interest of maximal production?

The War Labor Board also had the advantage over its immediate predecessor of speaking with more authority. The Defense Mediation Board could "formulate recommendations" for settlement; the War Labor Board can "finally determine the dispute" and use "arbitration" as well as "voluntary arbitration." Exactly what these words mean remains uncertain till put to the test. Perhaps the Board's final determining means that it or the interested party may enforce the Board's order by legal action. Certainly the present Board has the resources that were utilized to overcome disregard of the recommendations of the Mediation Board; and the President, if the need arises, is more likely now in time of war to use means of enforcement at his disposal.

Perhaps the War Labor Board's greatest advantage, apart from having the renewed cooperation of the CIO, was that the Mediation Board had explored the union security question and, though it had suffered the hard fate of many pioneers, had tried out the formula of "maintenance of membership" as a compromise union security measure. ${ }^{11}$

\section{UNION SECURITY}

For the union security problem, having unmanned the Mediation Board, cogently threatened the War Labor Board at the outset. Though the employers at the December conference had not succeeded in putting it outside the Board's jurisdiction, when the Board began to decree maintenance of membership (it has never ordered the closed or the union shop), the employer members reiterated their views in a series of dissenting opinions. ${ }^{12}$

The course of adjudication was this. On February 2I, the Board announced an interim decision in the Phelps Dodge Corporation case, postponing the union

${ }^{21}$ Frank P. Graham, a member of both boards, traces the development of this type of union security in his opinion accompanying the WLB's order in Part II of Ryan Aeronautical Co. (June I8). The Mediation Board's maintenance of membership decisions were made in the summer of 194x. Its only recommendation of any greater degree of union security (Bethlehem Steel Co., Shipbuilding Division, in which the Board voted for the union shop) was made then also. During the eight months from Aug. 7, 1941, to March 6, 1942, the date of the WLB's Marshall Field decision, neither board made a decision conditioning employment in any way on union membership.

${ }^{22}$ Lapham wrote dissents for all the employer members in Walker-Turner (April ro), International Harvester (April 15), and Federal Shipbuilding (April 25). McMillan wrote a dissenting opinion in Ryan Acronautical, Part II (June 18), where Lapham and Deupree of the employers reluctantly concurred with the majority. The employer members seemed to bow to a settled policy when they (Deupree and Mead) signed the Board order in Phelps Dadge (June 26) without comment; but they unitedly returned to dissent in Caterpillar Tractor (July 5) with an opinion by Lapham and in "Little Steel" (July I6) with an opinion signed by Lapham, McMillan, Mead and Horton. After steadily dissenting throughout July, the employers accepted the inevitable because "nothing constructive could be accomplished by continually voting No as a matter of principle," as they explained in a concurring opinion by Lapham and Black in S. A. Woods Machine Co. (Aug. I). 
security issue pending enunciation of "an authoritative national policy." On March $5^{13}$ in the case of Marshall Field and Co. (Spray, N. C., textile mill) it adopted, without opinion and with only one employer dissenting (without opinion), the unanimous recommendation of a panel that the contract oblige the employer (I) to give effect in its payment of wages to a writing thereafter voluntarily signed by any employee assigning wages (to the extent of $25 \mathrm{c}$ a week) to the union in payment of dues, and (2) to dismiss any employee breaking his pledge, contained in the same voluntary writing, to continue a member of the union for the duration of the contract.

Then, when the Inland Steel Co. at the start of the "Little Steel" case doubted its authority, the Board on March 18 unanimously resolved: "This Board has jurisdiction to consider all labor disputes which might interrupt work which contributes to the effective prosecution of the war, including labor disputes as to union status." And with unanimous support of the Board, the chairman on April 22, quoted this resolution in answer to a similar doubt raised by a speech of William P. Witherow, president of the National Association of Manufacturers.

By then the Board had disposed of two cases-Walker-Turner Co. on April 12 and International Harvester Co. on April 15-in each of which the panel had disagreed on the union security issue, and in them the Board had decreed maintenance of union membership as a condition of employment, the employer members in each case dissenting. Walker-Turner differed from Marshall Field chiefly in that (I) the maintenance obligation attached to all employees who were members on or after November 27, I94I, a long past date, instead of only to those who made a pledge of maintenance of membership after the date of the decision; and (2) there was in Walker-Turner no general check-off provision, and the obligation to maintain membership had a loophole-the employer might retain an employee who had lost union membership if the umpire under the contract agreed thereto and if the employee made, and the employer honored, for the duration of the contract a wage assignment to the union of the amount the employee would have owed the union as dues if he had remained in membership. Though the anti-union conduct of the particular employer makes the retroactivity of the order understandable, it was a feature which provoked strong dissents from the employer member of the panel and then from the 4 employer members of the Board. The other 8 members joined in the order substantially as recommended by the panel majority. But no subsequent decision has had a retroactive feature. Then in International Harvester, acting against the majority recommendation of a panel split 3 to 2, the Board ordered maintenance of membership provided it were endorsed by a majority of the mem-

\footnotetext{
${ }^{23}$ The dates tied to cases are those appearing on the news releases announcing decisions. Such publication ordinarily occurs on the day or the morrow of the Board's vote, but there is sometimes delay as in order that the parties may be first apprised or that Board members may complete opinions for simultaneous relcase. In the Marshall Field case the recommendations of the panel were "approved" on Feb. 13. Because the company doubted whether this imposed an obligation, the Board on Feb. 25 "finally determined" the controversy by a "directive order."
} 
bers of the bargaining union in an election conducted by the Board. The employer members placed their dissent on the Board's refusal to allow employees individually to opt whether to subject themselves to the rule. This group referendum variant was devised by the Board in order to test the stability of the bargaining unions in a group of plants where there had been strong AFL-CIO rivalry culminating in certification of the AFL in some plants and of the CIO in others. When the referendum vote was taken, maintenance of membership was strongly endorsed in every plant.

In the Federal Shipbuilding and Dry Dock Co. decision (April 25), the Board, without any panel report and with the employer members dissenting, required maintenance of membership with the Walker-Turner loophole (minus the approval of an umpire) but, as explained in Chairman Davis's opinion, applying only to members on or after the date of the contract then in negotiation. This was reiterating the solution of the controversy that had been recommended by the National Defense Mediation Board in July I94I, but had never actually been put into operation. ${ }^{14}$

In Robins Dry Dock and Repair Co. the panel's report was unanimous again, and, unlike Marshall Field but like Federal Shipbuilding, the recommendation did not require individual acceptance of the maintenance rule but imposed it on all who were members at or after the effective date of the contract. Though this clearly allowed employees an opportunity to withdraw from the union before the contract was completed, the employer members again dissented from the Board's order, ${ }^{16}$ which followed the panel report; and so they did from the similar decisions in Brown \& Sharpe Manufacturing Co., Nevada Consolidated Copper Corp., and Hotel Employers Association of San Francisco. ${ }^{16}$

The Board in deciding the Ryan Aeronautical Co. case ${ }^{17}$ varied the formula to make the starting date of the obligation to maintain membership not that of the completion of the contract in negotiation, but I $_{5}$ days after the date of the Board's decision. This Ryan type of maintenance of membership won some employer support in the Ryan, ${ }^{18}$ Ranger, E-Z Mills, and second Phelps Dodge ${ }^{19}$ decisions. In making them the Board overruled the mere voluntary check-off proposal of the panel in Ranger and rejected unanimously the alternative of the Walker-Turner loophole that was tendered by the panel in Phelps Dodge. After this momentary approach to unanimity, Caterpillar Tractor, "Little Steel," J. I. Case, U. S. Rubber,

\footnotetext{
It The Mediation Board recommendation (with employer dissent) had no "Walker-Turner loophole." It was that the contract contain a maintenance of membership clause covering "any employee who is now a member of the union or who hereafter voluntarily becomes a member during the life of this agreement." Whether the "now" meant the date of the recommendation or the date of completing the contract was never debated or decided. Exactly the same words were used in the WLB's order.

${ }^{15}$ Robins Dry Dock and Repair Co. (June 2).

${ }^{10}$ Announced June 3,4 , and 4 , respectively.

${ }^{17}$ June 18 . The accompanying opinions of the employer members apply also to Ranger Aircraft Engines and E-Z Mills (both June I2).

${ }_{18}$ Though announced later, Ryan was actually decided before Ranger and E-Z Mills.

${ }^{10}$ June 26.
} 
and Buckeye Cotton Oil ${ }^{20}$ divided the Board again on maintenance of membership. In all these cases a 55 -day period of choice was allowed to present union members.

After the unanimous decision in Phelps Dodge on June 26, it was a surprise to find all four employer members in opposition in Caterpillar Tractor on July 5. In writing the opinion of the Board in this case Wayne L. Morse, a public member, reviews at length the vicissitudes of the Board in dealing with union security. The opinion of another of the public members, Frank R. Graham, in the Ranger case had rehearsed the leading decisions of the Mediation Board and explained the theory of the public members in espousing maintenance of membership as a compromise between required union membership, generally desired by the labor group, and mere reiteration of the obligation of indifference imposed by the NLRA on all employers apart from contract, generally desired by the employer group. Dean Morse's opinion supplemented President Graham's by showing the course of discussion by which the employer members' offer, expressed in their International Harvester dissent, to acquiesce in maintenance of membership, if conditioned on an affirmative individual acceptance (as in Marshall Field) or if accompanied by an adequate opportunity of each employee to make individual withdrawal (as in Ryan), had been persuasive with the public members to create the Ryan type of order on maintenance of membership, which had been accepted, very reluctantly, by the labor members in the interest of unanimity on this troublesome question. But, having won their point, the employers now raised a new condition, namely, that the union, to obtain maintenance of membership by order of the Board, must agree to supply to the Board twice a year its financial statement and other data. Employer member Roger D. Lapham's concurring opinion in the Ryan case had indicated doubt because of this omission; now he announced his opposition and Morse took him to task for thus breaking the unanimity that had been wrought. Later in S. A. Woods Machine Co. (August I) Chairman Davis condemned this proposal "to extend a continuing control by the Board over a labor union" as "the worst vice of administrative tribunals-an attempt to extend jurisdiction beyond the frame of reference under [within] which the tribunal acts."

Throughout July the employers maintained their opposition unbroken and emphasized it in the "Little Steel" case, which added to membership maintenance compulsory check-off of union dues; but on August I, in the belief that "constant emphasis on disagreement could serve no useful purpose in this critical period," the employers rejoined the other groups in $S$. A. Woods Machine Co. and Borg-Warner Corp., decisions that probably mark the end of the cleavage, though the employer members by their concurring opinion "reserve their rights to reverse or revise their position ... particularly when they think because of some special facts the public interest would not be served by granting maintenance of membership."

\footnotetext{
${ }^{30}$ Caterpillar Tractor Co. (July 5); "Little Steel" (Bethlehem Steel Corp., Republic Stecl Corp., Youngstown Sheet \& Tube Co., Inland Steel Co.) (July 16); J. I. Case Co. (July 22); United States Rubber Co. (July 23); Buckeye Cotton Oil Co. (July 31).
} 
It will be remembered that in the Marshall Field formula the check-off was combined with maintenance of membership, and so it was in a secondary manner in Walker-Turner and Federal Ship. Not till "Little Steel" did the Board, and then without a panel recommendation, order both the check-off and maintenance of membership. They were again tied together in Buckeye Cotton Oil Co. (July 3I), with the employers dissenting on both points. But the check-off without maintenance of membership had been ordered without employer dissent in several earlier cases upon unanimous recommendations of panels. In one case, Bower Roller Bearing (March 12), the check-off was compulsory as to new members of the union. It was made compulsory, applying to all employees who were or became union members, in the "Little Steel" decision. In all other cases, before or since, it has been voluntary and revocable (revocable only on 60 days notice in Remington Rand); that is, the employer has been required to check-off only for those employees whose individual (voluntary and revocable) written wage assignments to the union for the specified amount have been presented to the employer.

Apart from maintenance of membership and the check-off of union dues, all union security provisions of the Board decisions are based on varying recommendations of unanimous panels. Discipline of opponents of the union, ${ }^{21}$ recommendation that new employees join, ${ }^{22}$ preference to unionists in hiring, ${ }^{23}$ are the several degrees and types of union security that have been thus endorsed by the Board in decisions during its early months. Since the Board began to grant maintenance of membership despite employer dissent, panels have almost ceased to recommend the less potent supports of union strength.

In other words, despite persistent denial that the Board is devising any patterns ${ }^{24}$ of labor settlement, there now appears to be a program of requiring maintenance of membership (after 15 days) and voluntary check-off if a worthy union asks for them or for any stronger form of union security. While various arguments for maintenance of membership have been set forth such as (I) offsetting an environment hostile to the bargaining union, due to community opinion, employer's conduct, or militance of a rival union; ${ }^{25}$ or (2) confirming a record of stability, fairness and responsibility of the bargaining union (e.g., that this is not the first contract between employer and union), ${ }^{28}$ apparently these are not necessary factors, for

${ }^{21}$ Armstrong Brothers Tool Co. (May 7 ).

${ }^{22}$ Babcock \& Wilson Co., Bayonne, N. J., plant (April 22).

${ }^{33}$ United States Lines (May 27); Hotel Employers Ass'n of San Francisco (June 2).

2t It is "impossible to devise any one pat formula or union maintenance clause that could be applied uniformly as a policy pattern to each and every case," says Morse in the concurring opinion in Caterpillar Tractor. Yet he "respectfully submits" that the employers are inconsistent in now dissenting, for "one will look in vain for any vital difference between the facts and circumstances of the Ryan, Ranger, E-Z Mills and Phelps Dodge cases and the instant case which will support this reversal of position on the part of the employers."

${ }^{25}$ See the panel report in International Harvester and second Phelps Dodge.

${ }^{20}$ See the panel report in Armstrong Brothers Tool Co. It may be further argued that since the policy of wage stabilization deprives unions of much of their economic appeal to waverers and since unions are valuable social institutions, there is now a peculiarly strong call for a policy of stabilizing union membership. 
opinions are often silent concerning them. A marked absence of the latter factor but not of the former would dissuade the Board ${ }^{27}$ from requiring dismissal for nonmaintenance of membership-or probably requiring check-off of dues-but the only positive reason given in some of the Board's best considered declarations is (3) the general one, applying to all cases, that is set forth in the following passage from the Board's opinion (per Graham) in Caterpillar Tractor-in part repeated in "Little Steel":

This maintenance of union membership on the part of those who exercise the choice to be bound by it, is simply an equitable consideration of [compensation for?] the union's giving up the right to strike for the union shop and the closed shop. By and large, this maintenance of a stable union membership makes for the maintenance of a responsible union leadership, the maintenance of loyal union discipline, and the maintenance of maximum production for winning the war.

The broadness of this basis made the employers point out in their "Little Steel" dissent:

Despite the varied facts in the ten cases [in which the Board had since June 2 decreed maintenance of membership], the public members of the Board have always found justification for ordering maintenance of membership. In the case before us the majority opinion is predicated on the fact that the union is well established and responsible. Yet in the Ranger Aircraft case the need for security by the union was based on its loss of members, and in the Caterpillar Tractor case the majority opinion, which implied a recognition of the present lack of responsibility on the part of the union, stated "This maintenance of a stable union membership makes for the maintenance of a responsible union leadership." The record clearly indicates that the concern of the public members of the Board has been for the formula. ... B But the employer members are unalterably opposed to the Board's present trend toward the application of this or any other formula as a concession to unions in all or most cases coming before it. Confirmed action of this sort by an agency of the government has the effect of law.

This pattern-making or fabrication of new reaches of law by the process of deciding actual cases-so congenial to our legal tradition-is taking place in other fields besides union security. But here it was most original, for maintenance of membership was scarcely known when the Mediation Board began to try it out,

${ }^{27}$ This appears to be the gist of the opinions in S. A. Woods Machine Co. (Aug. I). Messrs. Lapham and Black reveal the debate that preceded the opinionless 6-3 order for maintenance in U. S. Rubber: "In discussing the U. S. Rubber Company case the public members of this Board made plain their belief: .. . (d) That insofar as employers were concerned maintenance of membership should be required, regardless of whether employers are good, bad or indifferent, or are pro-labor, anti-labor or what-not.

"In the U. S. Rubber Company case it was unanimously conceded that the relations between employer and union were excellent and that there was nothing in the record of the company per se that justified or required a maintenance of membership clause. ...

"Presumably the granting of a maintenance of membership clause in the U. S. Rubber Company case fixes a pattern applicable to all employers. But it is yet to be determined if such a pattern will be applied in favor of all unions, whether they be responsible or irresponsible."

Chairman Davis quieted the employers" anxiety: "The employer members expressed their view that the maintenance of membership clause should not be granted to a union in a particular case unless the Board was satisfied that the union was responsible and was operated according to certain well-established democratic principles under its constitution and by-laws. The public members of the Board agree with the employer members in this respect completely." 
and is now most settled, for maintenance of membership as well as voluntary check-off is now likely to be awarded when asked for, unless the union is irresponsible or not "operated according to certain well established democratic principles."28

\section{Wages, Wage Differentials and Related Issues}

The question of wages-basic or standard wage rates-has come up more frequently than any other and has evoked more dissents than any other-or indeed than all others-except union security. Before the announcement of the President's seven-point stabilization plan on April 27th, the Board's decisions were tacitly or expressly based on vague considerations of fairness or equalization. ${ }^{28}$ (Permitting the reconsideration, before the general expiration of the contract, of wage rates upon notice of 30 or 60 days, or at stated intervals of 3 to 6 months, or on stated dates, or in one case $\mathrm{e}^{30}$ upon $5 \%$ change in cost of living, was a provision found in several orders before "Little Steel," but in none thereafter.) Since the "Little Steel" decision wage raises are ordered only (I) to correct "inequalities" between groups and (2) to correspond with the climb in cost of living. The first ordinarily requires a survey by the Bureau of Labor Statistics in which the wage rates in the instant plant are compared with those in (a) competing plants and (b) plants in the locality where similar skills are requisite. The relative weight of these factors is not clear. Quotations from recent opinions will give the best notion of the Board's attitude.

In the "Little Steel" case (July I6), the Board's opinion by George W. Taylor, public member and vice-chairman, states:

In full recognition of its grave responsibility to the nation, and for reasons later detailed in this opinion, the National War Labor Board has determined that the following guiding principles should be applied in evaluating claims for wage increases:

${ }^{28}$ Quoted from opinion of Chairman Davis in S. A. Woods Machine Co. (August I) stppra note 2\%. In the Borg-Warner case of the same day the Board awarded maintenance though the panel (in 2 report dated June II) had unanimously refused to recommend it. This solidification of the Board's policy between June II and August I is noteworthy.

The Woods case contains the latest standard edition of union membership provisions as follows:

"All employees who, 15 days after the date of the Directive Order of the.. . Board in this case are members of the Union in good standing in accordance with the constitution and by-laws of the Union, and those employees who may thereafter become members shall, during the life of the agreement, as a condition of employment, remain members of the Union in good standing.

"The Union shall promptly furnish to the ... Board and to the Company a notarized list of members in good standing 15 days after the date of the Directive Order. If any employee named on that list asserts that he withdrew from membership in the Union prior to that date and any dispute arises, the assertion or dispute shall be adjudicated by an arbiter appointed by the . . . Board whose decision shall be final and binding upon the Union and the employees.

"The Union agrees that neither it nor any of its officers or members will intimidate or coerce employees into membership in the Union. If any dispute arises (as to whether these has been any violation of this pledge or whether any employee affected by this clause has been deprived of good standing in any way contrary to the constitution and by-laws of the Union) the dispute shall be regarded as a grievance and submitted to the grievance machinery."

${ }^{20}$ Breeze Corps. (May 22), Chase Brass and Copper Co. (May 28), and of course "Little Steel" (July 16) contain particularly significant recognitions of the President's speech. Price ceilings were mentioned as a brake in an earlier panel report of which the Board adopted the wage recommendations, Walker-Turner (April ro). The Board approved the panel's recommendation of severance of the tie between wages and retail prices of the product (copper) in the Phelps Dodge cases (June 25).

${ }^{\text {so }}$ Babcock and Wilcox Co., Bayonne, N. J., plant (April 22). 
(I) For the period from January I, I94x, to May, I942, which followed a long period of relative stability, the cost of living increased by about $15 \%$. If any group of workers averaged less than a $15 \%$ increase in hourly wage-rates during, or immediately preceding or following, this period, their established peacetime standards have been broken. If any group of workers averaged a $15 \%$ wage increase or more, their established peacetime standards have been preserved.

(2) Any claims for wage adjustments for the groups whose peacetime standards have been preserved can only be considered in terms of the inequalities or of the sub-standard conditions specifically referred to in the President's message of April 27, r942.

(3) Those groups whose peacetime standards have been broken are entitled to have these standards reestablished as a stabilization factor.

(4) The Board, as directed by the President in his April 27th message, will continue to "give due consideration to inequalities and the elimination of substandards of living."

(5) Approximately twenty wage disputes, still pending before the Board, were certified prior to the stabilization date of April 27th. The question arises in these cases whether wage-rates being paid on April 27 th, I942 can or cannot be considered as "existing rates" within the meaning of the President's message or whether they then had the tentative character of disputed rates. Due regard must be given to any factors of equity which would be arbitrarily swept away by "a change of rules in the middle of the game."

The guiding principles outlined above insure, in general, that claims for wage-rate adjustment can be considered on an equitable basis and in a manner which will further the national purpose to stabilize the cost of living. Their use in the present case, however, is not to be construed as establishing an inflexible pattern to be rigidly followed if that would unnecessarily lead to injustice.

The opinion of the Board by Wayne L. Morse, public member, in Remington Rand Co. (July 27) states:

It is clear that the employees involved in this case are not entitled to a further wage increase at this time on the basis of any change in cost of living since January $r, 194 r$, in view of the wage stabilization formula laid down by the Board in its decision in the "Little Steel" case.

[Here the opinion quotes paragraphs ( $\mathrm{I}$ ) and (2) in the above quotation from the "Little Steel" opinion.]

It follows from an application of the Board's wage stabilization formula that the workers in the instant case have not suffered any lowering of their peacetime standards as they existed on January $\mathrm{r}$, I94 $\mathrm{I}$, because of any increase in cost of living in excess of wage increases from January $x$, I94I to May, I942. In fact, the record shows that these employees have received a percentage wage increase during that period of time in excess of the percentage increase in cost of living for the same period of time.

The Board then looked to see if the employees in these plants suffer from substandard wages or wage inequalities. It is satisfied from the record that the wages are not substandard but it does find, however, that the female employees hired on an incentive work basis do suffer from a wage inequality in the amount of two and one-half $(21 / 2 c)$ cents per hour. This inequality results from the fact that there has been a growing disparity between the wages paid men and women workers in the plants of the company....

The decision of the War Labor Board in this case demonstrates the applicability and workability of the wage stabilization formula which it has adopted. It will not follow, as publicized in the press, that an application of the formula will result in a huge increase in the Nation's wage bill, totaling three or more billion dollars. The National Asso- 
ciation of Manufacturers has called attention to the fact that over two thirds of the manufacturing industries of the country have already made increases equal to or in excess of the level fixed by the War Labor Board's formula. The other one third have made increases averaging close to the 15 per cent called for under the formula. Hence, the application of the Board's formula will result in only minor increases in the Nation's wage levels. Such wage increases as will be allowed by the formula will be so insignificant in contrast with the total wage bill of the country as to have no inflationary effect.

The Board is satisfied that if the formula is permitted time in which to work, it will result in a sound wage stabilization program. What the formula will do is place a terminal on the race between prices and wages and prevent the beginning of another upward spiral of general wage increases with their inflationary effects.

The formula permits of fair and reasonable adjustments of inequitable and substandard wages and it maintains reasonable standards of living necessary for maximum production of war materials. Contrary to some reports, it does not guarantee to labor that existing standards of living will be maintained throughout the war. Even before the "Little Steel" decision the Board had pointed out in several cases that labor cannot hope to receive wage increases which will enable it to keep pace with upward changes in cost of living.

After these firm and explicit pronouncements, it is clear that in wage determinations the Board has laid down rules that it intends to observe and to require others within its power to observe. ${ }^{31}$

In the field of overtime pay for work on the sixth and seventh consecutive day, the Board has sometimes approved "time and a half" for sixth day work ${ }^{32}$ and usually "double time" for seventh day work, sometimes with slightly different pro-

s2 These decisions still leave many wage problems outstanding, such as: ( $I$ ) what weight should be given to wage increases in the latter part of 1940 ; (2) what account should be taken of wage and cost-of-living changes after April 27, I942; (3) what effect should be given to proof that wages on January I, 194I, were exceptionally high in the plant, industry, or locality; (4) to what extent wage changes, based on (a) length of service, (b) upgrading, or (c) dilution (e.g., replacement of skilled workers by semi-skilied at a lower wage, or men by women at a lower wage), (A) when made after January I, I94I, should count in computing how far wage increases have kept pace with the cost of living, or (B) should be required to be made (or should be reckoned as if made in computing the wage increases needed to keep pace with the cost of living); (5) to what extent wage increases lessening inequalities (a) between occupations or sexes or races within the plant, or (b) between this plant and others in the locality or in the industry, or (c) between this locality and others (regional differentials), (A) when made after January $I$, I94I, should count in computing how far wage increases have kept pace with the cost of living, or (B) should be required to be made.

In addition to stabilization (cost of living) increases, the Board is likely to continue to do something in the direction of equalization at least in situation (5) above. Following the strong plea for such action by the dissenting panel member in Buckeye Cotton Oil Co., the Board's unanimous action (July $3 \mathrm{r}$ ) in giving the lower-paid (colored) workers a $6 \mathrm{c}$ raise and the higher-paid (white) workers a 4c raise (the amount recommended for all by the majority of the panel) is a striking instance of a wage raise for equalization of type 5 (a).

${ }^{83}$ But in International Harvester (April x5), Ryan Aeronautical (June 18) and Borg-Warner Corp., Warner Automotive Parts Division (Aug. I) the Board gave no special rate for the sixth consecutive day but only the double rate for the seventh consecutive day and of course the $150 \%$ "penalty" rate of the Fair Labor Standards Act for any work over 40 hours a week or 8 hours a day. In the last-named case the Board without explanation cut out the sixth-day overrate that had been unanimously recommended by the panel. No overrate for sixth-day work therefore seems to be the prevailing policy. A $150 \%$ rate for Saturday work under special circumstances (holidays or sickness earlier in the week) was approved in Bower Roller Bearing Co. (March I2), where the $4^{0}$ hours FLSA rule normally provided this higher ratc for Saturday work. 
visions where there is a "swing shift," which were worked out by the parties in the General Motors case ${ }^{33}$ and imposed by the Board in the Bendix Aviation case. ${ }^{34}$ The new wartime standard of no higher rate merely because work is performed on holidays, Saturdays and Sundays ("no overtime pay for Saturdays, Sundays, and holidays as such") recurs constantly in Board decisions with variations to suit differing situations. To some extent the higher rates for sixth and seventh day work overlap the statutory requirement of "time and a half" for all work in excess of $4^{\circ}$ hours a week..$^{35}$

Likewise, the Board, usually upon panel recommendation, has repeatedly granted $^{36}$ and never denied ${ }^{37}$ higher rates for night shift work. This was an issue in the first decision of the Board, ${ }^{38}$ an issue on which the Board divided 7-5 as to the amount of differential. The decisions do not show uniformity in the amount of night shift bonus. It has varied from $3^{c}$ for the evening shift in the case just mentioned to Ioc for the early morning shift. ${ }^{39}$

Another provision that seems to be tending toward standardization is the paid vacation (or, during the war period, pay of equal amount in lieu of vacation). But there is wide leeway in the relationship between ( $\mathrm{r}$ ) the length of service or the seniority of the individual and/or the time worked by the employee during the year in which the vacation was "earned" and (2) the duration of the vacation and/or the amount of vacation pay. The most that the Board has ordered is two weeks vacation and two weeks pay. ${ }^{40}$ Usually, but not always, the pay is what the employee would have earned during his vacation period, but earnings for a standard week are used rather than average earnings of the individual employee. ${ }^{41}$

${ }^{\text {ss }}$ Over the strong protest of the company (at public hearing before the Board on May 7 ) the Board required (orders of May $I$ and 2I) the whole of the expiring contract, including a double rate for Saturday and Sunday work to be extended for a month while the details of the new plan were being worked out.

${ }^{34}$ Bendix Aviation Corp., Bendix Products Division, South Bend, Ind. (July 6) allowing $150 \%$ pay on the sixth consecutive day, following unanimous panel recommendation. But compare Borg-Warnet Corp. (Aug. 1), supra note 32 .

${ }^{35}$ In maritime occupations the Board has never required double pay. A $150 \%$ rate was decreed in United States Lines (May 27) for work over 8 hours a day at sea (not covered by FLSA) and for night work, and in W. J. Conners Contracting Co. (June 17) for night, Sunday, and holiday work. The Board, without opinion and following the panel majority, refused to order any higher rate of pay for work over 40 hours a week in processing cottonseed (not covercd by FLSA) in Buckeye Cotton Oil Co. (July 31). There was an eloquent dissent in support of "time and a half" by the labor members (per Richard Frankensteen and Martin P. Durkin).

${ }^{30}$ (Besides cases mentioned in adjacent notes) Babcock \& Wilcox, Bayonne, N. J. (April 22) where the differential was $5 \%$ for shift $B$ and $7 \frac{1}{2} \%$ for shift $C$. The differential is usually expressed in cents. Compare note 44 , infra.

${ }^{37}$ But they were denied in an arbitration by a Board panel in American Smelting Co. (April 2).

3s Aluminum Company of America (Feb. ro).

${ }^{30}$ Breeze Corps. (May 22). Percentage allowances may run higher. See note 35 for extreme cxamples.

${ }^{40}$ Bower Roller Bearing Co. (March 12), Realty Advisory Board on Labor Relations (Aug. 3), both following unanimous panel recommendation.

"In White Sewing Machine Co. (May $x$ ) the Board adopted an elaborate rccommendation of a unanimous panel. The vacation was expressed in days (at the rate of $\mathrm{r} 1 / 4$ days for each six months of service, with a maximum of 5 days) and pay per day was to be 8 times hourly carnings at the standard rate ("straight time"). Elaborate vacation provisions for the lumber industry are contained in the arbi- 
Other ancillary questions about pay have arisen in too few cases to be indicative of any course of thought. ${ }^{2}$ Troublesome financial questions peculiar to the Boston fishing industry-who should pay for extra insurance costs on the fishermen's lives and personal effects due to the war?-were disposed of by a series of decisions in Federated Fishing Boats Co. (Feb. Io, April 2, and June I6). The matter of minimum pay rates has been dealt with in several cases, but these, as well as the effective date of pay raises and the duration and adjustment of wage scales, are so closely tied to the question of standard wages that they have meaning only in that relation. It may be said in general that pay increases (including differentials and ancillary pay changes) are made retroactive to the date of expiration of the former contract or, if never fixed by contract, usually to the date of certification of the case to the Board.

Frequently the minimum or entering wage $e^{43}$ or all lower wages have been raised by a larger percentage, ${ }^{44}$ or even a larger amount, ${ }^{45}$ than higher wages. Similarly the wage scale differential between northern and southern plants of the same company was lessened in the Board's very first decision. ${ }^{46}$

In no case has the Board ordered a lower wage than that prevailing. In many it has denied increases.

\section{Grievance Procedure and Other Issues}

The cases that deal with disagreements concerning grievance procedure and arbitration reveal only that the Board is trying to create adequate machinery for self-rule in collective labor relations; even to the point of requiring the parties to agree to arbitration. ${ }^{47}$ Nor is there need to comment on numerous other issues treated occasionally. ${ }^{48}$

trators' awards in Employers Negotiating Committee (Puget Sound Douglas Fir area), approved by the Board (June 17 and July 3 ). Here the maximum was five days and the pay (obtainable only if vacation was actually taken) was again on a "straight time" basis. In Phelps Dodge (June 25) the vacation plan recommended unanimously by the panel and adopted per ctriam by the Board, was simple: one week and 48 hours pay for cmployees who had worked a year or more. Proportionate vacation pay was allowed to persons who left to enter military service in Babcock \& Wilcox (April 22).

12 The Board ordered in International Harvester (April 15) that union representatives when employees should not lose pay while handling grievances. In New England Textile Operators (July 7) the Board "recommended to the consideration" of the employers the payments of "severance pay" to workers entering military service. In Breeze Corps. (May 22) the order required that men and women receive equal pay for the same work; more often, however, the Board had approved scales differentiating between men and women, though sometimes lessening the differential, as in Remington Rand (July 28). In each of the above-named cases the Board followed a unanimous panel recommendation.

${ }^{18}$ E.g., Ryan Aeronautical, Part I (June r8); Phelps Dodge (June 25).

"A wage increase of so many cents for all workers is the most usual prescription.

${ }^{45}$ E.g., Arcade Malleable Iron Co. (May I); New England Textile Operators (July 7).

40 Aluminum Co. of America (Feb. IO). The employer members dissented on the ground that the raising of the wage scale of the southern plants made it too disparate from the scale prevailing in the communities where the plants operated.

"Taterpillar Tractor (July 5); S. A. Woods Machine Co. (Aug. I). This is, of course, "compulsory arbitration."

48 These fall under four main heads: (I) Interim orders, pending final disposition by negotiation or by Board order, covering job classification studies, wage surveys, and a great variety of other matters; 


\section{Arbitration}

Limitations of time and space prevent consideration of the arbitration award; that have been made under Board auspices. They are in one sense part of the jurisprudence of the Board, but rather by reflection than by direction. In most cases, the Board merely appoints an arbitrator or arbitrators whose decision is final. In wage cases, however, it is now usual to require confirmation of the award by the Board. The terms of arbitration may allow the Board to revise the award or they may merely give the Board the choice between approval or rejection. Whichever the type, the awards are not likely to depart from discoverable principles of Board decisions; of those which the Board may revise or veto, none yet has failed to be confirmed. Several awards have been casually mentioned already. The fact that the decisions of arbitrators are not sharply scrutinized and controlled results, presumably, in their having less effect on subsequent decisions of the Board or of other arbitrators than do the original orders of the Board or the orders embodying or modifying recommendations of panels.

One class of arbitration requires special mention, that of controversies concerning demarcation of jurisdiction between unions. This is one of the many points where activities of the Board impinge on those of the National Labor Relations Boardcontacts which are now dealt with by the two boards on an ad hoc basis but which promise to come some day into the spotlight and to require more scientific treatment. "Jurisdictional disputes" involve the settlement of boundaries that correspond to those necessary for the NLRB to fix for collective bargaining. If such disputes are to be settled by government at all, the NLRB, rather than the War Labor Board, seems the qualified agency. ${ }^{40}$ But they often fall at or beyond the border of the NLRA power-as in cases of conflict between a production group and a building group over renovating buildings or installing new machinery or moving old machinery to new or remodeled buildings.

Due rather to the urgency of quick decision to hasten the installation of machinery for war production than to any theoretical considerations, the Board has actually, though quite unwillingly, required arbitration of several demarcation disputes. The AFL and CIO having failed to devise machinery for settlement of these controversies, the Board very early received certification of such a controversy concerning the outfitting of new buildings of the Toledo plant of the Spicer Manufacturing Company. This case was referred to a panel, but, as the panel's mediation was un-

(2) relations with the NLRB, the Office of Defense Transportation, and other government agencies as in Los Angeles Railway (Feb. I9), Sperry Gyroscope Co. (May 7), Central Foundry (June Ix), U. S. Cartridge Co. (July 4), and Ohio Public Service Co. (July $3 I$ ); (3) interpretation of contracts and refusal to order alteration of existing contracts, as in Midland Steel Products Co. (June II), though a change was recommended in Baocock and Wilcox (Feb. 27); (4) miscellancous terms of contracts in negotiation, such as race equality-Phelps Dodge (Feb. 19); "superseniority" for shop stcwards-Armstrong Tool (May 7); seniority-American Brass Co. (June 25); leave of absence on union businessBabcock \& Wilcox (April 22), Armstrong Tool (May 7).

${ }^{19}$ Compare Kingston Products Corp., a WLB case which was disposed of by a Grecn-Murray agrecment to refer it to the NLRB. 
successful, it returned to the Board which, after hearing the unions (the employer resting neutral), voted unanimously to leave it to arbitration by the chairman with the benefit of the consultation and advice of the three other public members. The award was made on February 20: electrical wiring and installation of new machines to be done by the AFL building trades and moving and remounting of old machines to be done by the CIO maintenance workers at the plant.

Then on April 2gth, Chairman Davis announced an AFL-CIO agreement whereby the labor members of the Board should thereafter settle such disputes, or, that failing, Presidents Green and Murray should appoint persons to settle them. But though this procedure yielded results in some cases, ${ }^{50}$ it failed in others and the Board, with ${ }^{51}$ or without ${ }^{52}$ concurrence of the labor members, ordered arbitration to prevent a work stoppage. After the Spicer case, it was felt to be preferable to divorce the Board from the settlement; so the Board put the responsibility of final decision on the arbitrator it appointed.

In July there was a strike because of a demarcation dispute which could not be settled without intervention of the Board. The situation evoked the following insistent telegram to the labor participants in the President's December conference, from two of the Board's employer members, Cyrus Ching and Roger D. Lapham:

At conference of labor and industry representatives called by the President last December the six AFL and six CIO members of that conference pledged themselves to no strikes or stoppages of work because of any dispute. Included in this category were all types of jurisdictional quarrels of whatever nature. The industry members of the conference as well as the general public accepted those pledges at their face value and assumed those pledges were given by those having authority to carry them out. There is a dispute at the Frigidaire plant of General Motors, Dayton, Ohio, involving the United Electrical Radio and Machine Workers of America CIO and Building Trades AFL. Since the morning of July $\mathrm{r} 7,25^{2}$ AFL building tradesmen have been on strike and in spite of requests made by unanimous resolution of War Labor Board have refused to go back to work. As employer members of the War Labor Board who participated as industry members in the December conference we are now publicly calling upon you twelve gentlemen to carry out the pledges given at the December conference.

Nor were the employer members the only ones who were aroused by the situation. Dean Morse had already mentioned in this connection that there were laws which punished treason; and the Board on July 25th voted, with the labor members dissenting:

Be IT REsolved, that the War Labor Board calls the attention of the AFL and the CIO to the fact that jurisdictional disputes during the war period should be settled by machinery set up by the two labor organizations. Whenever the two labor organizations fail to settle without delay a jurisdictional dispute that has led to a stoppage of work,

${ }^{50}$ E.g., Kingston Products Corp., supra note 49.

${ }^{81}$ E.g., White Construction Co. (June II), a contest between an AFL union and an unaffiliated union. Award by E. E. Witte, June 27.

${ }^{63}$ E.g., Kelly Springfield Engineering Co. (July 20), a contest between AFL unions and a CIO union. Award by W. G. Rice, Jr., July 23. 
the War Labor Board will appoint an arbitrator to render a decision, which decision shall be final and binding on the parties.

While this particular case was settled by the termination of the strike after the ClO had completed the disputed work and by the reference of the controversy to the War Production Board's board of review, there is no reason to think that the Board's resolution will be idle long.

\section{Dissents and Defaults}

In taking stock of the Board's divisions of opinion, it is plain that, apart from these formal dissents in demarcation cases and an occasional dissent by representatives of the defeated group in cases in which the AFL and the CIO have had conflicting interests, all the dissents by labor have concerned wages, while all but two of the dissents of the employer members have been protests against imposing maintenance of union membership as a condition of employment. Twice employers voted against wage awards-once against lessening a north-south differential, ${ }^{63}$ once against maintaining an existing $50 \%$ night shift differential. ${ }^{54}$ All public members of the Board have been in the majority in every part of every case, except that, in the initial Aluminum case, Morse voted with the labor members for a night shift differential of larger amount than was ordered.

The rate of rendering decisions is increasing steadily. So is the rate of receiving cases. So, it must be admitted, is the frequency of instances of work stoppage apparently designed to force certification. Thus the Board faces new problems of quantity and of kind and may have to meet them by changes in procedure and organization.

Another disquieting fact is that the roster of current cases-Allis-Chalmers, John A. Roebling's Sons, Cornell Dubilier, Aluminum Company of America, Bethlehem Steel (Shipbuilding Division), Phelps Dodge Copper Products, Western Pennsylvania Motor Carriers (formerly Labor Relations) Assn., Breeze Corporations. Standard Tool-sounds too much like the first 50 cases before the National Defense Mediation Board. Apparently much that was rated construction in I94I turns out to be only maintenance; there must be new expenditures of governmental energy to recement relations at the expiration of the $194 \mathrm{I}$ contracts.

\section{ConcLusion}

Despite its delays and disagreements the National War Labor Board is serving an essential function in the country's mobilization of resources and it is discharging its duties and utilizing its opportunities in a way which is winning growing respect from the parties and the public. No order has as yet been questioned by any legal proceedings. ${ }^{55}$ Only one final ${ }^{56}$ order has been flouted; the Toledo, Peoria, and

\footnotetext{
"s Aluminum Co. of America (Feb. I0). "W W. J. Conners Contracting Co. (June I7).

5o The Inland Steel $\mathrm{Co}_{0}$. has stated that it intends to sue to test the Board's authority to order maintenance of membership in the "Little Steel" decision.

${ }^{50}$ Several interim orders met with resistance temporarily, e.g., Federated Fishing Boats of New Eng-
} 
Western Railroad Co. refused to comply with the Board's order of February 27 to arbitrate. Thereupon by order of the President the Office of Defense Transportation took over and operated the road. Thus the President confirmed the Board's authority to require arbitration. And, as has been seen, the Board has since required arbitration or required parties to contract to arbitrate future disputes in enough cases to establish compulsory arbitration as a settled part of the Board's jurisprudence. Agreeing to settlement of all labor disputes by peaceful means is agreeing to have them settled by the Government if settlement by the parties fails. And whether the settlement be made by the Board itself or by its appointee-arbitrator or by an arbitrator appointed through other channels upon order of the Board, the nature of the settlement is the same. In all of them consideration by the Board, that is, by a tripartite agency, is a step at some stage of the procedure. And if the Board sees fit to condition all arbitral awards on confirmation by the Board, then consideration by a responsible public agency becomes the final step to the conclusion.

In this as in other matters the Board is developing a common law of labor relations for wartime, which can hardly fail to have profound permanent effects.

\section{Postscript}

After the completion of this article on August 3, the Board's orders in General Cable Co. (Bayonne, N. J.) and $S . A$. Woods Co. (Boston, Mass.) required presidential support. In the former case the employees struck because the Board denied a wage increase. The President put the Navy in charge. Selective Service deferments of employees were ordered cancelled unless work was resumed at once. The strikers immediately voted to return to work. The management was not displaced and the nominal control of the Navy was withdrawn after a few days. In the Woods case the employer notified the Board that it would not carry out the Board's union membership maintenance order. The President put the Army in charge and, production continued under the active control of the Army.

Other noteworthy events of the last four weeks of August are: (I) the northsouth differential was left unchanged in the textile cases (Aug. 21 ) $;{ }^{57}$ (2) the involuntary checkoff (over employer dissent on this and also on maintenance of membership) was ordered in "Big Steel" (Aug. 25) following the pattern of "Little Steel"; (3) the Board required equal pay for equal work where women replaced men in Norma-Hoffman Bearings Corp. (Aug. 24) ${ }^{58}$ (4) in Cambridge Tile Mfg. Co. (Aug. 12) Dean Morse again disagreed with his public colleagues and joined the labor group in favoring a night shift differential denied by the majority; ${ }^{59}(5)$ in Norma-Hoffman Bearings Corp. (Aug. 24) the Board's opinion defined the basis of granting maintenance of membership-that "it will result in industrial harmony and increased cooperation" and that "the Union is a responsible organization capable of

\footnotetext{
land (February), General Motors (May), General Motors Frigidaire (July), in effect a loud demand for reconsideration.

${ }^{57}$ Compare note 46 , supra. $\quad{ }^{58}$ Compare note 42 , supra.

${ }^{80}$ Compare text following note 54, stpra.
} 
fulfilling all of its obligations to its members, the management, and the Board," and in Monsanto Chemical Co. (Aug. 27), quoting this latter language, it unanimously followed a unanimous panel recommendation against union security of any form because the local union leadership and membership had violated its no-strike pledge; (6) the Board's decision in Pioneer Gen-E-Motor Co. (Aug. 3r) indicated the hardening of the union security mold, for the company having had for several years closed-shop agreements with a union representing its employees and, upon their voting a change of representation, having refused to make a closed-shop agreement with the new bargaining agent, and the panel having unanimously recommended maintenance of membership to take effect immediately, the Board ordered membership maintenance effective after I5 days, that is, merely the usual provision. 